\title{
Cross-Border Shopping: A Research Proposal For A Comparison Of Service Encounters Of Canadian Cross-Border Shoppers Versus Canadian Domestic In-Shoppers
}

Brian A. Zinser, Northern Michigan University, USA

Gary J. Brunswick, Northern Michigan University, USA

\begin{abstract}
The phenomenon known as out-shopping behavior (also known as intermarket patronage) is further explored and analyzed within the context of international cross-border consumer behavior. The authors provide an extensive literature review and a set of research hypotheses, as well as a suggested research methodology, and argue that this research will allow for significant contributions to the literature on out-shopping, international cross-border shopping, and services marketing.
\end{abstract}

Keywords: Out-Shopping; International Cross-Border Shopping; Services

\section{INTRODUCTION}

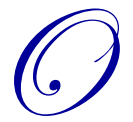

ut-shopping, also known as intermarket patronage, is a phenomenon where individuals leave their local trade area and travel to another - usually larger - trade area to shop for and purchase goods and services. When shoppers cross a political boundary, out-shopping becomes cross-border shopping (Sullivan \& Kang, 1997). While consumer demographics and motivations for out-shopping and cross-border shopping, in its broadest sense, may be similar, cross-border shopping introduces the potential of additional environmental factors, primarily differential sales and use tax rates between political jurisdictions.

International cross-border shopping introduces the potential for a plethora of additional variables which may motivate or hinder an individual to cross-border shop. In addition to differential sales and use tax rates between countries, some other variables, which may affect one's motivation to cross-border shop, include foreign currency exchange rates; duties, tariffs, and goods restrictions; governmental subsidies of commodities; availability and or quality of goods and services or specific brands; border crossing access, costs, and convenience; information sources; and one's degree of ethnocentricity, to name an obvious few (Piron, 2002).

The authors' interest in international cross-border shopping stems from the fact that they live and work in a region near the U.S./Canadian border. Several articles in the popular press, as well as macro-economic studies, have documented the ebb and flow of cross-border shopping between the United States and Canada. Historically, the ebbs and flows have been primarily attributable to the desirability or undesirability of the U.S./Canadian dollar exchange rate ("Business: A Nation of Angry Shoppers; Cross-border Shopping," 2007; "Business: You'd be a Loonie not to; Cross-border Shopping," 2007; Chipello, 1994; Di Matteo, \& Di Matteo, 1993; Lindstedt, 1995; Timothy \& Butler, 1995). There have been some other events that have presumably had macro-economic effects on cross-border shopping between the two countries. One was the North American Free Trade Agreement (NAFTA), which reduced or eliminated tariffs on products produced in either of the two countries and exported to the other. Although NAFTA 
primarily pertains to commercial transactions, one author has alluded to a psychological or halo effect on individual cross-border shopping behavior (Stafford, 1999). The incidents of September 11, 2002 and the subsequent tighter travel restrictions, including the implementation of the Western Hemisphere Travel Initiative by the United States, have also made it more difficult for Canadian citizens to travel - and American citizens to return - to the United States. Specifically, enhanced documentation, such as a passport, Nexus card, or enhanced driver's license is now required to enter the United States from Canada.

Cross-border shopping affects the local and regional economies, especially the retail, restaurant, entertainment, and media sectors of border communities and their residents of both nations along the U.S./Canadian border. Eighty percent of Canada's 34 million residents live within 100 miles, or less than a two-hour drive, from the U.S. border. Surprisingly, as the brief literature review will indicate, there has been relatively little academic research on international cross-border shopping, in general, and U.S./Canadian cross-border shopping, specifically. Most studies that have been done on Canadian cross-border shopping focus on macro-economic effects, like exchange rate fluctuations and tax rate differentials.

One study that is not focused on macro-economic effects was conducted by Sullivan and Kang (1997). They designed and executed a pilot study to determine information sources and motivational attributes of Canadian cross-border shoppers. Their study had a three-fold objective: 1) to describe the demographic characteristics of Canadian cross-border shoppers; 2) to investigate Canadian cross-border shoppers' sources of shopping information; and 3) to examine the motivational attributes of Canadian cross-border shopping. Their study was conducted nearly fifteen years ago and prior to 9-11. Additionally, they obtained their data from residents of Quebec which, due to its Francophone culture, is arguably a significantly different sampling frame than the rest of Canada (Hofstede, 1983).

While more narrowly focused on one aspect of cross-border consumption, Lord, Putrevu, and Parsa (2004) have more recently studied the U.S./Canadian cross-border experience of dining. They examined variables that motivate or inhibit consumers to cross borders to patronize restaurants. Sampling cross-border diners in the Buffalo/Niagara region of New York and Ontario, the researchers used factor analysis and eventually identified the existence of eight dimensions related to cross-border dining behavior. Subsequent cluster analysis identified three motivational segments for cross-border dining.

The authors propose to expand on the knowledge obtained by Sullivan and Kang's (1997) pilot study and the work performed by Lord et al. (2004). A cross-border shopping research project, which examines whether Canadian cross-border shoppers' service encounters in the United States differ from similar service encounters of Canadian domestic in-shoppers in Canada, is being suggested. Borrowing methodology from international services research done by Keillor, Hult, and Kandemir (2004) and based on service theory developed by the Nordic school of services marketing (NSSM) (Grönroos, 1982, 1984, 1990; Grönroos \& Gummesson, 1985) the authors propose a cross-sectional study and collecting data from a sample of primarily English speaking Canadians from the Algoma District of Ontario.

\section{PROPOSED RESEARCH STATEMENT, RESEARCH HYPOTHESIS, AND KNOWLEDGE CONTRIBUTION}

As the following brief literature review will show, existing academic research on cross-border shopping is relatively scarce and existing research on U.S./Canadian cross-border shopping is not only more scarce, but dated. The potential contributions of findings could lead to the development of predictive model building and theory development. Practical applications of any findings would be of use to retailers, restaurateurs, entertainment providers, local chamber of commerce associations, local units of government, and media providers on both sides of the border. For these reasons, the authors are proposing a research study to expand upon earlier work that has been conducted of U.S./Canadian cross-border shopping and consumption, as well as cross-border shopping in other cultural contexts.

Lord et al. (2004) expanded the concept of cross-border shopping to cross-border consumption, of which shopping was identified as one of its five major dimensions. Tourism, business, dining, and entertainment were identified as the other four dimensions. Since the provision of services now accounts for a major portion of 
multinational corporations' business (Lovelock \& Yip, 1996), it seems fitting that a study of cross-border shopping be expanded to include other dimensions of cross-border consumption which are more service-oriented, like dining and entertainment.

Keillor et al. (2004) drew upon the theory developed by the NSSM (Grőnroos, 1982, 1984, 1990; Grönroos \& Gummesson, 1985) and constructed a model that includes constructs and measurements that examine the effects of technical quality and functional quality aspects of service encounters and their effects on one's behavioral intentions. They devised a construct to measure physical goods quality to represent technical quality and constructs to measure service quality and servicescape to represent functional quality, and they tested the constructs effects on customers' behavioral intentions in two embedded service categories - fast food and groceries.

Since quality of goods and services has been cited as a motivation for out-shopping, the authors propose adopting the service encounter model developed by Keillor et al. (2004) to examine the research problem, "Do Canadian in- and cross-border shoppers perceive technical quality and functional quality elements of service encounters in Canada and the United States differently?" Like Keillor et al. (2004), the authors propose using the same two embedded services categories - fast food and groceries - plus the addition of a third category - gaming.

Specifically, the following research hypothesis is proposed: There is no difference in the technical quality and functional quality elements of service encounters between Canadian cross-border shoppers shopping for goods and services and consuming services in the United States and Canadian in-shoppers shopping for goods and services and consuming services in Canada. Before the proposed research methodology to test the research hypothesis is presented, a brief literature review follows.

\section{LITERATURE REVIEW}

\section{Out-Shopping}

While the literature on cross-border shopping is quite scarce, there is a rich literature stream with regard to the phenomena of out-shopping. Reilly's (1931) "Law of Retail Gravitation Models" suggested that a shopper's choice of a shopping area is a rather complex decision that involves a tradeoff between the attractiveness versus the unattractiveness of shopping in a particular area. Bender (1964) defined consumer purchase costs as consisting of both the monetary cost and non-monetary secondary costs such as finding the item, completing the purchase, and getting the item home. Herrmann and Beik (1968) noted that early studies on shopping out of one's local area primarily investigated intra-market shopping. They appear to be the first academics to study "out-of-town" shopping and coined the terms out-shopping and out-shoppers. They defined out-shoppers as shopping outside a five-mile radius of the downtown area at least once a year. Their study of out-shoppers in central Pennsylvania concluded that shopping mobility influenced out-shopping. Lower-income families and those with younger or a large number of children out-shopped less frequently. They also found that the desire for larger and more varied selections of soft goods was the principal factor motivating out-of-town shopping. Higher-income families were more concerned with selection while lower-income families were more motivated by lower prices.

Defining out-shopping as making at least one out-of-town purchase every six months, Thompson (1971) researched small town out-shopping in Georgia and found higher income households more prone to out-shopping and incidents of out-shopping inversely related to one's age. He also found that in the United States, Caucasians tend to out-shop more frequently, suggesting racial and sub-cultural influences might exist. He found no significant differences between the frequency of out-shopping and family size but found a positive correlation to lower prices, and, like Herrmann \& Beik (1968), he found that more frequent out-shoppers indicate that local limited selection of merchandise, particularly goods with an element of fashion, is an important motivator to out-shop.

While the above studies primarily focused on demographics of out-shoppers, Reynolds and Darden (1972) noted that out-shopping appears to be for goods where fashion and self-expression is important. Using data collected from female homemakers in the small city of Dublin, Georgia, they defined out-shoppers as individuals who shopped outside the local trade area at least once a month. They found three demographic variables which were significant between frequent and infrequent out-shoppers. Frequent out-shoppers tend to be in the 25 to 54 age 
group, have a head of household with some higher education, and have relatively high household incomes. The psychographic results of their findings suggest that frequent out-shoppers tend to be very active but not time sensitive nor loyal to any particular store. They also expressed a general dissatisfaction with local shopping conditions and a preference for larger urban shopping areas.

Lillis and Hawkins (1974) studied out-shopping in Oregon's Willamette Valley and reported findings which indicated that out-shoppers, with higher percentages of purchases out of the shopper's local shopping area, were dissatisfied with both selection and quality of soft goods and consumer durables. They also perceived local prices for out-purchased goods as being higher. Significant evidence was found to support that younger aged heads of household and smaller number of individuals in a household tend to make a larger percentage of purchases out of their local shopping area.

Like Lillis and Hawkins (1974), Samli and Uhr (1974) chose to define out-shopping on the basis of the proportion of total dollar purchases made out-of-town rather than using an arbitrary dichotomous frequency rule. The spectrum of out-shoppers they developed resulted in a typology of shoppers consisting of heavy out-shoppers, out-shoppers, in-shoppers, and loyal in-shoppers. Their findings were not significantly different from the previous studies above. However, they identified some new socio-economic variables of out-shoppers. The heavy outshoppers group consisted more heavily of males and had a larger number of people between the ages of 20 and 34 in the family unit and a smaller number of people between the ages of 35 and 49 in the family unit. They also found that the tenure of the family unit in the community was inversely related to the spectrum of out-shopping, wives of family units of the heavy out-shoppers group were less educated, and that total family income of the heavy outshoppers group was relatively less. Moving across the spectrum from loyal in-shoppers to heavy out-shoppers found that the level of satisfaction of the quality of goods offered, selection of goods offered, and prices of goods offered decreased with respect to local shopping facilities.

A Canadian researcher, Papadopolous (1980), conducted an extensive literature review and concluded that almost all out-shopping studies had focused on the behavior of shoppers from smaller communities who migrate to larger trade areas to shop. Using a mid-sized Canadian city as his "test city," he found that 20 percent of all consumer expenditures in eight product classes tested were out-of-town purchases in spite of the fact that the test city was relatively isolated. (The closest cities in the United States were 200 miles away, while the next larger cities in Canada were 500 and 1,000 miles away.) He found that out-shoppers of the isolated test city primarily outshopped for products that are less bulky, easy to carry, and not extremely expensive. Like previous researchers, price competitiveness, merchandise selection, and merchandise quality were attitudes that were expressed by consumers for out-shopping. While the previous studies highlighted above have found that service is an attribute for inshopping in smaller communities, residents of the Canadian mid-sized test city indicated that in-store service, or lack thereof, was a reason for out-shopping. Papadopolous also found that out-shopping is not necessarily prevalent in product categories where dissatisfaction of one's local area merchants is most pronounced.

Citing that smaller communities require almost everyone to be an out-shopper and that residents of smaller communities tend to be homogenous, Samli, Riecken, and Yavas (1983) studied out-shopping behavior of residents of a small Midwestern community. While previous studies had only attempted to measures resident's dissatisfaction with local facilities, their study looked at out-shoppers' relative dissatisfaction/satisfaction of local retail facilities vis-à-vis those in relatively close neighboring communities. Using the number of out-shopping trips per year as an indicator, they found no significant difference in all of the demographic variables tested as a predictor of more frequent out-shopping (sex, home ownership, age, income, marital status, occupation, housing, length of residence, possession of out-of-town department store credit cards, and possession of bank credit cards). More frequent outshoppers tended to purchase apparel and apparel-related products as well as gift or hobby-related products away from home. Frequent and less-frequent out-shoppers did relatively more out-shopping for "shopping goods" such as home furnishings, furniture, appliances, and automobiles.

Stating that the "jury is still out" with regard to a number of out-shopping issues, Hawes and Lumpkin (1984) argued that replication of previous research is a requirement for the advancement of any discipline. They conducted an inter-market patronage study, or out-shopping study, using a sample that consisted of households from 14 communities, ranging in population from 1,000 to more than 50,000 and located within a one and one-half hour 
drive of Dallas-Fort Worth. Similar to Lillis and Hawkins (1974), Samli and Uhr (1974), and Samli et al. (1983), they chose to segment out-shoppers into three groups based upon the frequency of out-shopping during the previous twelve-month time frame. Demographic and socio-economic variables, psychographic constructs, and perception measurements of various features of a shopping area were collected.

With the exception of findings by Samli and Uhr (1974) and Samli et al. (1983) they found that the more frequent out-shoppers had higher incomes than occasional out-shoppers who, in turn, had higher incomes than inshoppers. Frequent out-shoppers also tended to own their own home. The education level of male heads of household was found to be higher among frequent out-shoppers versus less formal education among in-shoppers. Consistent with findings by Samli and Uhr (1974), they found some evidence that males tend to be more frequent out-shoppers. They also found some evidence to support previous findings that there is a negative correlation between frequent out-shopping and age (e.g., Lillis \& Hawkins, 1974; Papadopoulos, 1980; Reynolds \& Darden, 1972; Samli \& Uhr, 1974; Thompson, 1971).

Of the 19 psychographic variables studied, 11 were individually related to inter-market patronage, including holding a negative attitude toward local shopping conditions, being less loyal to local merchants, being a shopping innovator, having more generalized/shopping self-confidence, being more of a generalized/shopping opinion leader, using more credit, being more physically fit, being a fashion innovation/opinion leader, being a less captive shopper, having a more favorable shopping mall orientation, and shopping less by catalog. In addition to replicating previous research to support demographic, socio-economic and psychographic variables, Hawes and Lumpkin (1984) specifically investigated the importance of shopping area attributes. Citing that no previous research in the area had been found, they learned that in-shoppers attributed more importance to the presence of beauty salons/barber shops and other services and that frequent out-shoppers attributed less importance to convenient location and ease of access.

Reidenback, Cooper, and Harrison (1984) indentified two basic problems with out-shopping studies up to this point which limit the generalization of results and the development of theory. While the concept of out-shopping appears to be universally understood, previous studies have used different definitions of it, or uniquely operationalized the concept for a particular study. The other problem the authors noted is that previous studies have only studied out-shopping in one general trade area and, moreover, most of the trade areas have been small in size.

Using two larger trade areas in different parts of the United States (Baton Rouge, Louisiana and LansingEast Lansing, Michigan), and using frequency of respondents out-shopping behavior as a dichotomous process of classifying out-shoppers, Reidenback et al. (1984) used principal component factor analysis and found three primary factors which had high factor congruence between both markets. They concluded that it appears that generalized out-shopping behavior is motivated by inadequacy of assortment, perceived friendliness of the stores, and the facility to engage in out-shopping. Their findings are consistent with most of the aforementioned studies, especially the selection or assortment dimension (e.g., Herrman \& Beik, 1968; Thompson, 1971; Reynolds \& Darden, 1972; Samli \& Uhr, 1972; Lillis \& Hawkins, 1974; Papadopoulos, 1980).

Hozier and Stem (1985) cited the few studies which had attempted to predict out-shopping behavior and commented on their reported weak relationships and lack of generalizability across geographic boundaries and product classes (e.g., Reynolds \& Martin, 1974; Bellenger \& Hirschman, 1978; Nevin \& Houston, 1980). Using a sampling frame which consisted of respondents from four small cities in eastern Washington and northern Idaho, they conducted an exploratory study to exam whether general retail patronage loyalty showed a stronger relationship with out-shopping behavior than attitudes toward specific local retailers. They found that retail patronage loyalty not only appears to have a stronger relationship, but that it may be generalizable across geographic boundaries. Their findings were consistent with Papadopoulos' (1980) findings in that product categories, where dissatisfaction of one's local area merchants is most pronounced, does not always translate into out-shopping behavior.

Many studies have researched demographics, psychographics, and motivational factors of out-shoppers. Varshney and Goyal (2005) published a comprehensive literature review of out-shopping to provide necessary inputs to start studying the phenomena in an Indian context. Reviewing 34 articles that dealt with the issue directly, they attempted to identify the antecedents of out-shopping behavior. They segmented the antecedents into 
demographic variables, psychographic variables, shopping area attributes, product-related factors, and accessibility factors.

Based on their review of the existing literature, they concluded that the following demographic variables were generally found to be positively associated with out-shopping: education, smaller family size, income, and automobile ownership. Likewise, they found the following variables to be negatively associated with out-shopping: age, family life cycle state, age of children, number of children, and tenure in the community. Other factors were determined to define variance in out-shopping behavior, including gender and cultural backgrounds.

Further, Varshney and Goyal (2005) grouped the following psychographic variables as being believed to be positively associated with out-shopping behavior: urban orientation, financial optimism, level of confidence, shopping innovation, self-consciousness, shopping enjoyment, fashion consciousness, level of price sensitivity, need for uniqueness, and dissatisfaction with local retail conditions which lead to out-shopping proneness. One's time consciousness, loyalty attitude in shopping, and social orientation were grouped as being negatively associated while one's shopping orientation leads to a variance in out-shopping behavior. Shopping area attributes, which were perceived as positively associated with out-shopping, included the overall city image of the out-of-town market, dissatisfaction with local retailing, negative perception about value being offered by local retailers, multiplicity of options in larger establishments, price reductions by out-of-town retailers and parking facilities. Lower prices, more product variety, and higher quality of service of the local market were associated negatively with out-shopping. Lifestyle products were felt to be a product-related variable positively associated with out-shopping, while the factor of convenience in travel was also positively associated with out-shopping. Meanwhile, the factor of distance was negatively associated with out-shopping.

In summary, while there is agreement among researchers of the primary motivation for out-shopping behavior; i.e., financial benefits, greater selection of merchandise, higher quality of goods and services, there have been inconsistencies with the findings of demographic profiles which describe typical out-shoppers (Dmitrovic \& Vida, 2007).

\section{Cross-Border Shopping And Canadian Cross-Border Shopping}

Cross-border shopping and consumption studies that have dealt with demographic characteristics, motivational attributes, ethnocentricity, and information sources are surprisingly scarce on a global level (Dmitrovic \& Vida, 2007). There is a plethora of cross-border shopping economic studies (Ahmed, 1996; Asgary, De Los Santos, Vincent, \& Davila, 1997; Bygvra, 2000; Campbell \& Lapham, 2004; Chandee \& Mieczkowski, 1987; Cleroux, 1990; Di Matteo, 1993, 1999; Di Matteo \& Di Matteo, 1996; Ernst and Young, 1991; Kreck, 1985; Patrick \& Renforth, 1996; Stafford, 1999; Timothy, 1999). While many of these cross-border shopping economic studies are conducted in the context of the U.S./Canadian border, international cross-border shopping studies, and particularly U.S./Canadian cross-border shopping studies which focus on socio-psychological and personal characteristics, are nearly non-existent.

Early studies of Canadian cross-border shopping motivation include Evans, Lane, and O'Grady (1992). Specifically examining cross-border shopping of Canadians, they found that lower prices, greater variety, and better service seemed to be the primary motivating factors. They also found a positive association between Canadian crossborder shopping and Canadian cross-border shopper's exposure to U.S. media. Similarly, an Ernst and Young (1991) cross-border shopping study conducted in the greater Kingston, Ontario, region found that Canadians perceived there to be better prices and selection for shopping in the United States. Salesperson friendliness and days and hours of operation were viewed more favorably too.

Conducted more than fifteen years ago, a Canadian cross-border shopping study was published by Sullivan and Kang in 1997. Described as a pilot study, their research objectives were to describe demographics of Canadian cross-border shoppers, to research Canadian cross-border shoppers' shopping information sources, and to investigate motivational attributes of Canadian cross-border shopping. They used a self-administered mail survey instrument that was sent to households in the greater Montreal area. They found that 41 percent of households identified themselves as cross-border shoppers and that the incidence rate was higher in English and bilingual households 
versus French-speaking households. No other demographic variables researched; i.e., sex, marital status, age, educational level, or family income, was found to be significantly different between cross-border shoppers and non cross-border shoppers. Differences were found in frequency of trips and spending levels depending upon one's differential levels of being reached by U.S. and Canadian information sources. They did not find any statistically significant evidence to support the hypothesis that Canadian cross-border shoppers who spend more time traveling to shop spend more dollars per cross-border shopping trip in the United States. Finally, they identified two factors which motivate consumers to cross-border shop - merchandise and service quality factors and economic factors.

Lord et al. (2004) studied the U.S./Canadian cross-border consumption experience of dining. They examined the variables that motivate or inhibit consumers to cross borders to patronize restaurants. Sampling crossborder diners in the Buffalo/Niagara region of New York and Ontario, factor analysis identified the existence of eight dimensions - ethnocentrism, value drivers, variety seeking, awareness, affective/social considerations, ease of border crossing, perceived differences between restaurants on both sides of the border, and distance from the border. Affect/social considerations, which affected consumers positively, and ethnocentrism, which affected consumers negatively, were the two factors with the strongest and most consistent effects. Subsequent cluster analysis identified three motivational segments for cross-border dining: 1) those which have a desire for variety which they labeled "variety seekers," 2) those whose motivations are inhibited by border-crossing issues which they labeled "comfort seekers," and 3) those who had a combination of economic/quality value drivers and affective/social considerations which they labeled "value seekers."

In addition to the few U.S./Canadian non-economic cross-border studies, there has been a splattering of studies of cross-border shopping behavior around the globe. Piron (2002) examined the cross-border shopping behavior and attitudes of Singaporeans in neighboring Malaysia, specifically the influence of demographic and retail characteristics on cross-border shopping. He also explored the impact of secondary consumer costs associated with cross-border shopping as well as a consumer's willingness to cross-border shop. Finally, he examined the effect of consumer ethnocentrism on cross-border shopping behavior.

Like previous out-shopping studies (Thompson, 1971; Reynolds \& Darden, 1972; Samli \& Uhr, 1974; Lillis \& Hawkins, 1974; Papadopoulos, 1980; Hawes \& Lumpkin, 1984), Piron (2002) found that younger persons tended to cross-border shop more frequently than older persons. He also found that frequent cross-border shoppers are more likely to be married, have less formal education, and have blue collar occupations. Retail characteristics were not found to be a motivating factor for cross-border shopping in Malaysia. Both infrequent and frequent crossborder shoppers perceived Singapore to have higher quality and a wider selection of products and better service. However, frequent cross-border shoppers perceived there to be higher prices in Singapore, prompting Piron to suggest that lower prices seemed to be the motivating factor for frequent cross-border shoppers. Overall, all respondents reported low ethnocentrism. Frequent cross-border shoppers strongly disagreed that cross-border shopping was "un-Singaporean."

Piron (2002) observed that some of his findings; i.e., that frequent out-shoppers tended to have lower incomes, lower education levels, and blue collar occupations, differed from most previous out-shopping demographic behavior findings and he suggested that there are different types of international out-shoppers. He proposed that future research might discriminate between utilitarian and touristic out-shopping. Based on the geographical proximity of the two countries in his study, he argued that his respondents exhibited mostly utilitarian behavior.

Kim and Sullivan (2003) identified four segments into which to classify international shoppers. Their proposed matrix classification scheme is based upon two dimensions - the degree to which one is a tourist versus the degree that one is a shopper. They have labeled the four quadrants of their tourism shopper segmentation matrix as: 1) "Traditional tourists" who are high on tourism and low on shopping, 2) "Traditional out-shoppers" who are low on tourism and high on shopping, 3) "Cross-border tourism shopper" who are high on tourism and high on shopping, and 4) "inactive tourists/shoppers" who are low on tourism and low on shopping. They suggest that retailers who know which segment they are serving can develop more effective strategies to meet the needs of the targeted segment. 
Wang (2004) studied Hong Kong residents crossing the border to shop and consume in Shenzhen. He found that consumers' motivations for cross-border shopping were both functional and recreational. The most important motivational reasons cited were similar to those of previous studies and included lower prices, better quality, goods and services not found in home area, better customer service, comfortable shopping environment, and convenient opening hours.

Dmitrovic and Vida (2007) studied cross-border shopping of consumers living in Croatia and in Serbia and Montenegro. A discriminant analysis of cross-border out-shoppers and domestic in-shoppers in the two countries confirmed the unstable effect of demographic variables on cross-border shopping behavior and established the significant role of economic patriotism in consumer decision-making.

Defining out-shoppers as individuals who take shopping trips abroad at least once every three months, Dmitrovic and Vida (2007) found no significant differences in affluence between Croatian out- and in-shoppers. Although they found that Croatian out-shopping was primarily economically driven, a lower level of "economic patriotism" was also found to be a significant predictor of out-shopping behavior. They defined economic patriotism as individuals who have higher consumer ethnocentrism, perceive buying local as having a positive impact on one's community, and a favorable perception of the quality of domestic goods. Like Croatians, they found that Serbian consumers' "economic patriotism" motives were significant predictors of out-shopping behavior. However, they found both affluence and having more children below the age of 18 in the household as significant predictors of outshopping in Serbia versus Croatia.

Guo and Wang (2009) used the framework of tripartite consumer response models to research cross-border out-shopping determinants. Using Mexican nationals cross-border shopping in the United States as their sampling frame, they found that both quality of merchandise, quality of service, and fashion consciousness were positively related to cross-border shopping frequency. They also found that cross-border shopping frequency is positively related to patriotism. Conducted post 9-11, their findings did not indicate that terror was among the determinant factors for deciding whether or not, or how frequently, to cross-border shop. They also measured cross-border shopping enjoyment and found that quality of merchandise, fashion consciousness, and patriotism are positively and significantly related to cross-border shopping enjoyment, but not quality of service of the retail establishments. Terror threats also had no significant relationship on shopping enjoyment.

\section{The U.S./Canadian Border and the Canadian Market}

Statistics Canada (2010) reported that the population of Canada is estimated to be more than 34 million. Four-fifths of Canada's residents live within 100 miles of the U.S. border (Custred, 2008). While one of the wealthiest nations in the world, the per capita income gap between Canada and the United States was still \$6,400 per person in 2008 (Conference Board of Canada). Although having been depressed for several years, the value of the Canadian dollar has recently risen against the U.S. dollar and is currently hovering around par (Bank of Canada). Since World War II, Granatstein (1997) points out that Canada's economic integration with the United States has increased dramatically as American goods, brands, and media products have become ubiquitous across Canada. Canada and the United States had an established free trade agreement prior to the adoption of NAFTA in the early 1990s.

Hofstede's (1983) Canada cultural dimension's analysis is similar to the United States. Individualism has the highest ranking and success is measured by personal achievement. Canadians tend to be self-confident and open to discussions on general topics; however, they hold their personal privacy off limits to all but the closest friends. Citizens of Quebec tend to be more private and reserved. Ethnocentrism is high throughout Canada, but particularly high in Quebec. This may be, in part, due to the difference in religious background of the French population which is predominately Catholic and the English population which is predominantly Protestant. The lowest ranking dimension is long-term orientation. This low ranking is indicative of societies' belief in meeting its obligations and tends to reflect an appreciation for cultural traditions. Canada's power distance is relatively low too, which is indicative of a greater equality between societal levels, including government, organizations, and even within families. 


\section{PROPOSED RESEARCH METHODOLOGY}

\section{Overview of Proposed Research Methodology}

The authors propose using a cross-sectional, retrospective, non-experimental research design to conduct a comparative study, using the services model developed and validated by Keillor et al. (2004), of service encounters of Canadian cross-border shoppers versus Canadian in-shoppers. Primary data would be collected using a selfadministered online questionnaire.

\section{Operational Hypotheses Development}

Keillor's et al. (2004) model to study technical quality and functional quality elements of service encounters on shopper's behavioral intentions is based on the prediction that the constructs of physical good quality, service quality, and servicescape all have an effect on one's behavioral intentions (see Figure 1). The four constructs are described as follows:

- $\quad$ Physical good quality is “the consumer's [subjective] judgment about a product's overall excellence or superiority" (Zeithaml, 1988, p. 3).

- $\quad$ Service Quality is "the consumer's overall impression of the relative inferiority/superiority of the organization and its services" (Bitner \& Hubbert, 1994, p. 77).

- $\quad$ Servicescape is the environment in which the service is delivered and where the firm and the customer interact (Baker \& Cameron, 1996).

- $\quad$ Behavioral intentions "can be viewed as an indicator that signals whether customers will remain with or defect from the company" (Zeithaml, Berry, \& Parasuraman, 1996, p. 33).

Based on NSSM theory, the Keillor et al. (2004) model uses the physical good quality construct to measure the technical, or outcome, dimension of the customer service encounter. Although physical good quality is just part of the customer service encounter (Grönroos, 1990), it has a positive effect on shopper's behavioral intentions (Normann, 1984). As such, the following hypotheses are proposed to be researched:

$\mathbf{H}_{\mathbf{1}}$ : $\quad$ Canadian in-shopper's perception of physical goods quality is positively associated with customer's behavioral intentions.

$\mathbf{H}_{1 \mathbf{b}}$ : Canadian cross-border shopper's perception of physical goods quality is positively associated with customer's behavioral intentions.

In addition to the technical dimension of the service encounter, Keillor et al. (2004) indicate that customer's behavioral intentions are influenced by the functional quality aspects of the exchange. The functional quality includes both the service quality and servicescape of the service encounter (Grönroos, 1982, 1990). They note that in concert with NSSM theory, although intuitive, there is ample support in the service quality literature that customers' subjective evaluation of the service quality is tied directly to customer's behavioral intentions (e.g., Boulding, Kalra, \& Staelin, 1999; Boulding, Kalra, Staelin, \& Zeithaml, 1993; Cronin \& Taylor, 1992; Parasuraman, Zeithaml, \& Berry, 1994; Zeithaml, Berry, \& Parasuraman, 1996). Furthermore, they attribute Kelly and Davis (1994) with the notion that equity theory suggests that customers who perceive higher service quality with the delivery of goods perceive greater equity in the relationship. Therefore, the following service quality hypotheses with be researched:

$\mathbf{H}_{1 \mathbf{c}}$ : Canadian in-shoppers' perception of service quality is positively associated with customers' behavioral intentions.

$\mathbf{H}_{\mathbf{1 d}}$ : Canadian cross-border shoppers' perception of service quality is positively associated with customers' behavioral intentions.

While not as researched as the above two constructs, Keillor et al. (2004) assert that there is evidence to support that servicescape also effects customers' behavioral intentions (e.g., Baker \& Cameron, 1996; Baker, Grewal, \& Levy, 1992; Bitner, 1990, 1992, Donovan, Rossiter, Marcoolyn, \& Nesdale, 1994); thus, the final two hypotheses to be research having an effect on behavioral intentions are: 
$\mathbf{H}_{1 \mathrm{e}}$ : Canadian in-shopper's perception of servicescape is positively associated with customer's behavioral intentions.

$\mathbf{H}_{1 \mathbf{f}}$ : Canadian cross-border shopper's perception of servicescape is positively associated with customer's behavioral intentions.

A secondary research objective of the study will be to test Dmitrovic and Vida's (2007) interpretation of existing evidence related to demographic variables of out-shoppers in the context of Canadian in- versus crossborder shoppers. They found mixed results in Serbian and Croatian samples. The following demographic hypotheses will be tested:

$\mathbf{H}_{2 \mathbf{a}}$ : Canadian cross-border shoppers will have higher levels of education than in-shoppers.

$\mathbf{H}_{\mathbf{2}}$ : The education of the most educated member of a household will be higher for Canadian cross-border shoppers than in-shoppers.

$\mathbf{H}_{2 \mathrm{c}}$ : Canadian cross-border shoppers will have a higher household income than in-border shoppers.

$\mathbf{H}_{2 \mathrm{~d}}$ : Canadian cross-border shoppers will have a greater number of children age 18 and under than in-shoppers.

\section{CONCLUSION}

Conducting this research will be a significant contribution to the literature on out-shopping, cross-border shopping, and international cross-border shopping, as well as services marketing. Although its results will be limited in scope and may not be generalizable across service encounter industries or other cross-border cultural contexts, it would add to the existing literature on cross-border shopping as well as contribute to the development of predictive model building and possible theory development. The results will also provide valuable information to retailers, restaurateurs, entertainment providers, chamber of commerce associations, media companies, and others to better target and attract cross-border shoppers as well as potentially convert cross-border shoppers to non cross-border shoppers, depending upon one's marketing objective.

The findings of the secondary research objectives; i.e., demographic variables, may or may not provide additional descriptive evidence of the researched demographic variables of out-shoppers, particularly in the context of Canadian cross-border shoppers. This, too, will expand upon research in this area.

\section{AUTHOR INFORMATION}

Brian Zinser is ABD in marketing from the Falls School of Business at Anderson University (Indiana). Now a member of the marketing faculty at Northern Michigan University, he served on the faculty of Lake Superior State University from 2005-2014. Previously, he spent nearly twenty years in marketing management positions in the financial services industry as well as served for more than five years as director of marketing for Northern Michigan University. Zinser holds an A.B. from the University of Illinois at Urbana-Champaign and a M.M. from the J.L. Kellogg Graduate School of Management at Northwestern University.

Gary J. Brunswick holds a Ph.D. in Business Administration from Arizona State University and currently holds the rank of Professor of Marketing at Northern Michigan University. His research interests include marketing strategy, services marketing and e-commerce. His research has been published in a range of journals, including Journal of the Academy of Marketing Science, Journal of Consumer Behaviour, The Marketing Management Journal, The Journal of Professional Services Marketing, The Journal of Business and Economics Research, The International Journal of Case Studies and Research, The Journal of the International Academy of Case Studies, The Academy of Educational Leadership Journal, and The Academy of Marketing Studies Journal. E-mail: gbrunswi@nmu.edu (Corresponding author)

\section{REFERENCES}

1. Ahmed, Z. (1996). An international marketing perspective of Canadian tourists' shopping behaviour: Minot (North Dakota). Journal of Vacation Marketing, 2(3), 207-214.

2. Asgary, N., De Los Santos, G., Vincent, V., \& Davila, V. (1997). The determinants of expenditures by Mexican visitors to the border cities of Texas. Tourism Economics, 3(4), 319-28. 
3. Baker, J. (1986). The role of the environment in marketing services: The consumer perspective. In J. Czepeil, C. Congram, \& J. Shanahan (Eds.), The service challenge: Integrating for competitive advantage (pp. 79-84). Chicago: American Marketing Association.

4. Baker, J., \& Cameron, M. (1996). The effects of the service environment on affect and consumer perception of waiting time: An integrative review and research propositions. Journal of the Academy of Marketing Sciences, 24(4), 338-349.

5. Baker, J., Grewal, D., \& Levy, M. (1992). An experimental approach to making retail store decisions. Journal of Retailing, 68(4), 445-60.

6. Bank of Canada (2010, November 12, 2010). US\$/CAN\$ closing rate summary [Chart]. Retrieved November 12, 2010 from http://bankofcanada.ca/en/rates/can_us_close.html

7. Bellenger, D., \& Hirschman, E. (1978). Geographic generalizability: An experiment without shopper models. Review of Business and Economic Research, 13(3), 71-79.

8. Bender, W. (1964). Consumer purchase costs-Do retailers recognize them? Journal of Retailing, 11(1), 18 .

9. Bitner, M. J. (1990). Evaluating service encounters: The effects of physical surroundings and employee responses. Journal of Marketing, 54(2), 69-82.

10. Bitner, M. J. (1992). Servicescapes: The impact of physical surroundings on customers and employees. Journal of Marketing, 56(2), 57-71.

11. Bitner, M. J., \& Hubbert, A. (1994). Encounter satisfaction versus overall satisfaction versusquality, In R. Rust and R. Oliver (Eds.), Service quality: New directions in theory and practice. (pp. 72-84). New York: Sage Publications,

12. Boulding, W., Kalra, A., \& Staelin, R. (1991). The quality of double whammy. Marketing Science, 18(4), 463-84.

13. Boulding, W., Kalra, A., Staelin, R., \& Zeithaml, V. (1993). A dynamic model of service quality: From expectations to behavioral intentions. Journal of Marketing Research, 30(1), 7-27.

14. Brucks, M., Zeithaml, V., \& Naylor, G. (2000). Price and brand name indicators of quality dimensions for consumer durables. Journal of the Academy of Marketing Science, 28(3), 359-74.

15. Business: A nation of angry shoppers; Cross-border shopping. (2007, November 10). The Economist, 385, 96.

16. Business: You'd be a loonie not to; Cross-border shopping. (2007, August 4). The Economist, $384,56$.

17. Bygvra, S. (2000). Retail trade at European borders. European Retail Digest, 27(1), 39-40.

18. Campbell, J., \& Lapham, B. (2004). Real exchange rate fluctuations and the dynamics of retail trade industries on the U.S.-Canada border. American Economic Review, 94, 1194- 1206.

19. Carsky, M., Dickson, R., \& Canedy, C. (1998). The evolution of quality in consumer goods. Journal of Macromarketing, 4(2), 9-28.

20. Chandee, D., \& Mieczkowski, Z. (1987). An empirical analysis of the effects of an exchange rate on Canadian tourism. Journal of Travel Research, 13-17.

21. Chipello, C. (1994, July 7). Retailing: Mighty barrier stops Canadians at U.S. border: Exchange rate. Wall Street Journal (Eastern Edition), B1.

22. Cleroux, P. (1990, October). Borderline business: Taxation and cross-border shopping. Canadian Federation of Independent Business, Toronto.

23. Conference Board of Canada. (2010, November 12). Economy - income per capita [Graph]. Retrieved November 12, 2010 from http://www.conferenceboard.ca/HCP/Details/Economy/income-per-capita.aspx

24. Cronin, J., Brady, M., \& Hult, G. T. (2000). Assessing the effects of quality, value, and customer satisfaction on consumer behavioral intentions in service environments. Journal of Retailing, 76(2), 193218.

25. Cronin, J., \& Taylor, S. (1992). Measuring service quality: A reexamination and extension. Journal of Marketing, 56(3), 55-68.

26. Custred, Glynn (2008). Security threats on America's borders. In A. Moens \& M. Collacott (Eds.), Immigration policy and the terrorist threat in Canada and the United States (pp. 95-112). Toronto: Fraser Institute.

27. Dmitrovic, T., \& Vida, I. (2007). An examination of cross-border shopping behaviour in South-East Europe. European Journal of Marketing, 41(3/4), 382-395. 
28. Di Matteo, L. (1993). Determinants of cross-border trips and spending by Canadians in the United States: 1979-1991. Canadian Business Economics, 1(3), 51-61.

29. Di Matteo, L. (1999). Cross-border trips by Canadians and Americans and the differential impact of the border. Visions in Leisure and Business, 17(4), 72-92.

30. Di Matteo, L., \& Di Matteo, R. (1993). The determinants of expenditures by Canadian visitors to the United States. Journal of Travel Research, 31(4), 34-42.

31. Donovan, R., Rossiter, J., Marcoolyn, G., \& Nesdale, A. (1994). Store atmosphere and purchasing behavior. Journal of Retailing, 70(3), 283-94.

32. Ernst and Young. (1991, July). The impact of cross-border shopping. A study for the Kingston District Chamber of Commerce. Toronto, Canada.

33. Evans, W., Lane, H., \& O’Grady, S. (1992). Border crossings. Scarborough, Ontario: Prentice Hall Canada, Inc.

34. Garvin, D. (1987, November). Competing on the eight dimensions of quality. Harvard Business Review, 6, 101-109.

35. Gotlieb, J., Grewal, D., \& Brown, S. (1994). Consumer satisfaction and perceived quality: Complementary or divergent constructs? Journal of Applied Psychology, 79(6), 875-85.

36. Granatstein, J. (1997). Yankee Go Home: Canadians and Anti-Americanism. Toronto: HarperCollins.

37. Grönroos, C. (1982). Strategic management and marketing in the service sector. Helsingfors, Finland: Swedish School of Economics and Business Administration.

38. Grönroos, C. (1984). A service quality model and its marketing implications. European Journal of Marketing, 18(4), 36-44.

39. Grönroos, C. (1990). Strategic Management and Marketing: Managing the Moment of Truth in Service Competition. Lexington, MA: Lexington Books.

40. Grőnroos, C., \& Gummesson, E.(1985). Service Marketing - Nordic School Perspectives. Stockholm: Stockholm School of Economics.

41. Guo, C., \& Wang, Y. (2009). A study of cross-border outshopping determinants: Mediating effect of outshopping enjoyment. International Journal of Consumer Studies, 33(6), 644-51.

42. Hawes, J., \& Lumpkin, J. (1984). Understanding the outshopper. Journal of the Academy of Marketing Science, 12(4), 200-18.

43. Hartline, M., \& Ferrell, O. (1996). The management of customer-contact service employees: An empirical investigation. Journal of Marketing, 60(4), 52-70.

44. Herrmann, R., \& Beik, L. (1968). Shoppers' movements outside their local retail area. Journal of Marketing, 32(4), 45-51.

45. Hightower, R. (1997). Conceptualizing and measuring servicescape's impact on service encounter outcomes. (Unpublished doctoral dissertation). Florida State University, Tallahassee, Florida.

46. Hofstede, G. (1983). The cultural relativity of organizational practices and theories. Journal of International Business Studies, 14(2), 75-89.

47. Hozier, G. \& Stem, D. (1985). General retail patronage loyalty as a determinant of consumer outshopping behavior. Journal of the Academy of Marketing Science, 13(1), 32-46.

48. Kelly, S., \& Davis, M. (1994). Antecedents to customer expectations for service recovery. Journal of the Academy of Marketing Science, 22(1), 52-61.

49. Keillor, B. D., Hult, G. T., \& Kandemir, D. (2004). A study of the service encounter in eight countries. Journal of International Marketing, 12(1), 9-35.

50. Kim, E. \& Sullivan, P. (2003). Cross-border tourism and shopping: Consumer segmentation. e-Review of Tourism Research (eRTR), 1(1), 14-20.

51. Kreck, L. (1985). The effect of the across-the-border commerce of Canadian tourists on the city of Spokane. Journal of Travel Research, 24(1), 27-31.

52. Leimgruber, W. (1988). Border trade: The boundary as an incentive and an obstacle to shopping trips. Nordia, 22(1), 53-60.

53. Lewis, K. (1990). Buying across the border. Canadian Consumer, 20(3), 9-14.

54. Lillis, C., \& Hawkins, D. (1974). Retail expenditure flows in contiguous trade areas. Journal of Retailing, 50(2), 30-42.

55. Lindstedt, S. (1995, March 25). Cross-border shopping now goes the other way. Buffalo News, Business Section. 
56. Lord, K., Putrevu, S., \& Parsa, H. (2004). The cross-border consumer: Investigation of motivators and inhibitors in dining experiences. Journal of Hospitality \& Tourism Research, 28(2), 209-229.

57. Lovelock, C., \& Yip, G. (1996). Developing global strategies for service businesses. California Management Review, 38(2), 64-86/

58. Nevin, J., \& Houston, M. (1980). Image as a component of attraction to intraurban shopping areas. Journal of Retailing, 50(1), 77-93.

59. Normann, R. (1984). Service management. New York: John Wiley \& Sons.

60. Papadopoulos, N. (1980). Consumer out-shopping research: review and extension. Journal of Retailing, 56, 41-58.

61. Parasuraman, A., Zeithaml, V., \& Berry, L. (1985). A conceptual model of service quality and its implications for future research. Journal of Marketing, 49(4), 41-50.

62. Parasuraman, A., Zeithaml, V., \& Berry, L. (1994). Reassessment of expectations as a comparison standard in measuring service quality: Implications for future research. Journal of Marketing, 49(1), 6-17.

63. Patrick, J., \& Renforth, W. (1996). The effects of the peso devaluation on cross-border retailing. Journal of Borderlands Studies, 11(1), 25-41.

64. Piron, F. (2002). International out-shopping and ethnocentrism. European Journal of Marketing, 36(1/2), 189-210.

65. Reidenback, R. E., Cooper, M. B., \& Harrison, M. (1984). A factor analytic comparison of outshopping behavior in larger retail trade areas. Journal of the Academy of Marketing Science, 12(2), 145-158.

66. Reilly, W. (1931). The law of retail gravitation, Knickerbocker Press, New York.

67. Reynolds, F., \& Darden, W. (1972). Intermarket patronage: A psychographic study of consumer outshoppers. Journal of Marketing, 36( ), 50-54.

68. Reynolds, F., \& Martin, W. (1974). A multivariate analysis of intermarket patronage: Some empirical findings. Journal of Business Research, 2(2), 193-200.

69. Samli, A. C., Riecken, G., \& Yavas, U. (1983). Intermarket shopping behavior and the small community: Problems and prospects of a widespread phenomenon. Journal of the Academy of Marketing Science, 11(2), $1-14$.

70. Samli, A. C., \& Uhr, E. (1974). The outshopping spectrum: Key for analyzing intermarket leakages. Journal of Retailing, 50(2), 70-78.

71. Stafford, Beverly Janine (1999). The determinants of cross-border shopping in New Brunswick. M.A. dissertation, The University of New Brunswick (Canada), Canada.

72. Sullivan, P., \& Kang, J. (1997). Information sources and motivational attributes of Canadiancross-border shoppers: A pilot study. International Journal of Commerce \&Management, 7(1), 88-107.

73. Statistics Canada (2010, September 29). Canada's population estimates [Table]. Retrieved November 12, 2010, from http://www.statcan.gc.ca/daily-quotidien/100929/dq100929b-eng.htm

74. Timothy, D. (1999). Cross-border shopping: Tourism in the Canada-United States borderlands. Visions in Leisure and Business, 17(4), 4-18.

75. Timothy, D., \& Butler, R. (1995). Cross-border shopping: A North American perspective. Annals of Tourism Research, 22(1), 16-34.

76. Thompson, J. (1971). Characteristics and behaviors of outshopper consumers. Journal of Retailing, 47(1), 70-80.

77. Varshney, S., \& Goyal, A. (2005). A review and extension of the outshopping paradigm to the Indian context. Asia Pacific Journal of Marketing and Logistics, 17(4), 30-63.

78. Wang, D. (2004). Hong Kongers' cross-border consumption and shopping in Shenzhen: patterns and motivations. Journal of Retailing and Consumer Services, 11(3), 149-159.

79. Voss, G., Parasuraman, A., \& Grewal, D. (1998). The roles of price, performance, and expectations in determining satisfaction in service exchanges. Journal of Marketing, 62(4), 46-61.

80. Zeithaml, V. (1988). Consumer perceptions of price, quality, and value: A means-end model and synthesis of evidence. Journal of Marketing, 52(3), 2-22.

81. Zeithaml, V., Berry, L., \& Parasuraman, A. (1996).The behavioral consequences of service quality. Journal of Marketing, 60(2), 31-46.

82. Zeithaml, V., \& Bitner, M. J. (2000). Services marketing: Integrating customer focus across the firm. Boston: Irwin/McGraw-Hill. 

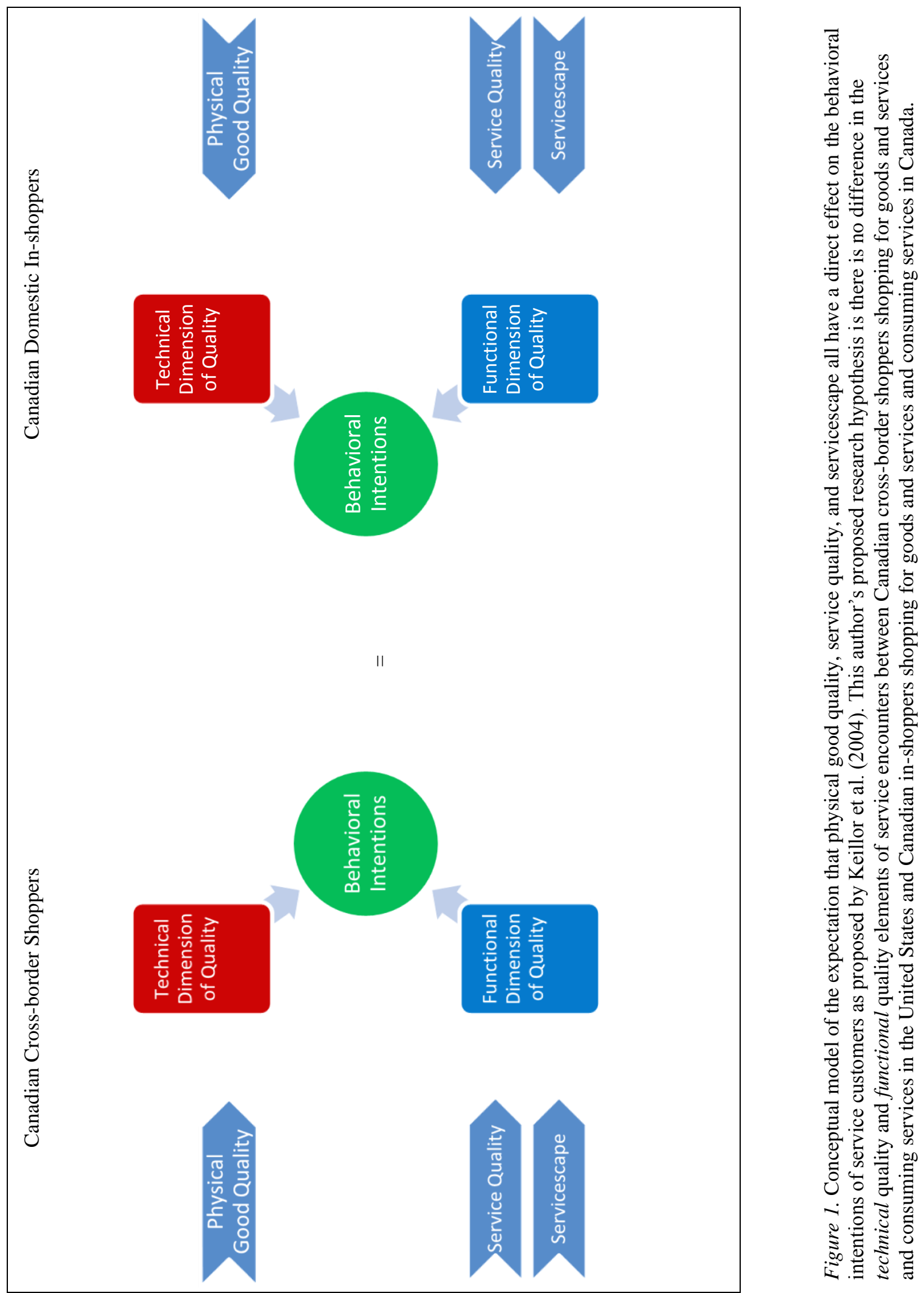